\title{
СИНТЕЗ И АНАЛИЗ АНТИБАКТЕРИАЛЬНОЙ АКТИВНОСТИ НОВЫХ СИММЕТРИЧНЫХ БИСПИРИДИНИЕВЫХ СОЛЕЙ С 2,7-ДИОКСИНАФТАЛИНОВЫМ СПЕЙСЕРОМ
}

\author{
Н.А. Фролов ${ }^{1}$, А.Н. Верещагин ${ }^{1}$, А.С. Пакина ${ }^{1,2}$ \\ 1 Институт органической химии им. Н.Д. Зелинского РАН, \\ 119991, Москва, Ленинский пр., 47. \\ 2 Российский химико-технологический университет им. Д. И. Менделеева, \\ 125047, Москва, Миусская пл., 9.
}

DOI: 10.19163/MedChemRussia2021-2021-338

E-mail:nikitafrolov298@gmail.com

Четвертичные соли пиридиния и биспиридиния (БПС) представляют важную группу химических веществ, широко применяемых в качестве биоцидов, благодаря их сильному противомикробному действию даже при очень низких концентрациях, на широкий спектр грамположительных и грамотрицательных бактерий, грибов и некоторых вирусов [1]. По своему строению БПС можно разделить на три типа, которые в общем представляют собой два ядра пиридиния, между которыми заключен спейсер [2, 3].

Нашей лабораторией было разработано несколько новых БПС с ароматическими спейсерами, которые имеют сходные или превосходящие значения минимальной ингибирующей концентрации на ряд патогенных штаммов бактерий и грибов по сравнению с известными биоцидами $[4,5,6]$. В продолжении этой темы был осуществлен синтез и анализ антибактериальной активности симметричных солей на основе 2,7-диоксинафталина с различными замещениями в пиридиниевом ядре. Полученные соединения ппроявили хорошие микробиологические свойства на фоне широко использующихся на рынке антисептиков и дезинфектантов.

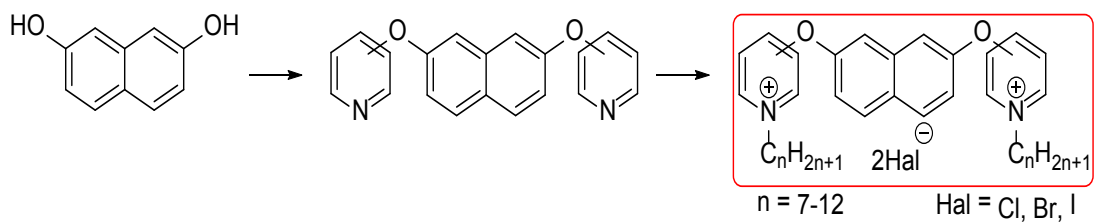

Работа выполнена при поддержке гранта РФФИ 19-33-90066

\section{Литература}

1. Chanawanno, K. et al. Eur. J. Med. Chem., 2010, 45, 4199-4208.

2. Kourai, H. et al. Eur. J. Med. Chem., 2006, 41 (4), 437-444.

3. Vereshchagin, A. N. et al. Pat. Appl. WO 2014/158045.

4. Vereshchagin, A. N., Frolov, N. A. et al. Eur. J. Org. Chem., 2019, 4123-4127.

5. Vereshchagin, A. N., Frolov, N. A. et al. Mend. Comm., 2019, 29, 523-525.

6. Верещагин А.Н., Фролов Н.А., Егоров М. П. Патент 2019, РФ104009. 